methylene blue, quinine and propamidine are neutralized by riboflavin, but the antagonistic action is probably more complex than in the other instances given. The growth-stimulating properties of aneurine are neutralized by pyrithiamine, the effect being complete or partial according to whether the organisms require the whole or only a part of the aneurine molecule. It had also been observed that the pyrophosphate of the thiazole moiety of aneurine will inhibit carboxylase activity, suggesting that cocarboxylase and the thiazole pyrophosphate compete with one another for the carboxylase protein.

Dr. F. Bergel, opening the discussion on these papers, said there are reasons for differentiating between the major vitamins, aneurine, riboflavin and nicotinic acid, and the minor vitamins, other than the reasons mentioned by Mr. Robinson. He pointed out that the major vitamins are highly specific in their action, only very closely related substances being effective, whereas the minor vitamins can be replaced by a number of analogues, and he cited pantothenic acid and its derivatives as an example. Other speakers in the discussion, however, deprecated the attempt to distinguish between major and minor vitamins, and suggested that in a few years time, both groups may be regarded as equally important. There was also disagreement with the suggestion that folic acid, vitamin $\mathrm{B}_{\mathrm{C}}$ and the $L$. casei $\varepsilon$ factor are identical.

At the afternoon session, under the chairmanship of Dr. L. J. Harris, Dr. B. S. Platt read a paper on "Fermentation and Human Nutrition". He showed a series of slides, illustrating the manufacture of Kaffir beer, and compared its nutritional value with that of British beer. Although the latter contains appreciable quantities of vitamins, it contains far less than Kaffir beer, and it was believed that this drink supplies factors which are otherwise lacking in the native diet. This was clearly brought out by a study of natives in the West Indies, who suffered from various deficiencies such as greying of the hair, cheilosis and various forms of dermatitis unknown among similar races in Africa where Kaffir beer is a staple article of diet. Investigation showed that when cereal grains germinate, the amounts of most members of the vitamin $\mathrm{B}$ complex present increase and that most of these factors are extracted in the steeping process, so passing into the resulting liquor. Although ruminants undoubtedly rely on fermentation in the rumen as the main source of supply of the vitamin B factors, it is not yet possible to state with certainty what contribution is made by bacterial fermentation in the intestinal tract to the vitamin requirements of man. Later, Dr. Platt showed a series of slides, some in colour, illustrating the symptoms of vitamin deficiency encountered during his recent visit to Labrador and Newfoundland.

Dr. Lucy Wills spoke on "The Vitamin B Complex in Anæmia", dealing especially with nutritional macrocytic anæmia and its relation to Addisonian pernicious anæmia. Nutritional macrocytic anæmia has formerly been regarded as due to a deficiency of an extrinsic factor which, according to Castle, is converted by the action of the intrinsic factor in the gastric juice into the anti-pernicious anæmia factor, which is stored in the liver. If Castle's theory is justified, nutritional macrocytic anæmia should be cured by any extract active in pernicious anæmia however given, but this is not the case. Dr. Wills therefore advanced an alternative theory, that this type of anæmia is due to the absence of a factor belonging to the vitamin $\mathrm{B}_{2}$ complex which does not, as Castle postulated, react with the intrinsic factor to give the liver principle, nor is it an essential part of the latter, though necessary for its proper functioning. In support of this theory, Dr. Wills stated that uncomplicated nutritional macrocytic anæmia in Bombay does not respond to purified liver extracts, but does respond to crude liver extracts and to yeast extracts by injection as well as by mouth. Furthermore, monkeys, in which a similar type of anæmia has been artificially induced, also respond to crude, though not to purified, liver extracts given by mouth or by injection, and to yeast extracts administered by either route. This shows that it is not necessary for the responsible factor to come into contact with the gastric juice. Just before the War, attempts were made to isolate the factor from liver extract; and although it was established that riboflavin, pyridoxine, pantothenic acid and probably nicotinic acid are ineffective, no conclusive results were obtained, as the work was interrupted.

In opening the discussion on the afternoon's papers, Dr. F. Prescott suggested that synthesis of the vitamin $\mathrm{B}$ complex by bacteria in the intestine is not of great importance in man. Najjar and Holt gave aneurine in amounts greatly in excess of the physiological requirements and, when the experiments were repeated with smaller amounts, no evidence that the vitamin was excreted in the urine was obtained. Dr. Prescott suggested that the results of sulphonamide treatment are due not to inhibition of bacterial synthesis, but to direct interference with the respiratory mechanism of the body, simulating the effects of irradiation sickness and drug anæmia.

Speakers who took part in the subsequent discussion supported Dr. Platt's view as to the nutritional value of native-fermented liquors, and cited other examples of how native populations made good a deficiency of the vitamin B factors, for example, by drinking the contents of the rumen of freshly killed animals. The necessity for providing an adequate diet for the Colonial populations was stressed. The proceedings of the meeting were summarized by Dr. Harris, bringing to a conclusion a memorable meeting, which attracted a very large audience.

\section{GENETIC TYPES OF MANGANESE DEPOSITS}

A COMPARATIVE study of the manganese deposits of the U.S.S.R. by A. G. Betekhtin, based on intensive investigations carried out during the last few years, adds considerably to our knowledge of the conditions governing the formation of manganese ores (Bull. Acad. Sci. U.R.S.S., No. 4, 3 ; English summary, $43 ; 1944)$.

Three groups of marine manganiferous sediments are distinguished :

(a) Most of the Palæozoic and Tertiary deposits are associated with siliceous and less common ferruginous chemical sediments, including radiolarian jaspers frequently accompanied by volcanic tuffs. The Tertiary ores of Chiatura, Transcaucasia and Polunochnoye, N. Urals, furnish typical examples similar to the classic deposits of Nikopol in the Ukraine. In the shallow-water facies formed near a shore of Cretaceous limestone, coarse pisolitic and massive psilomelane and pyrolusite occur. Farther 
out, the pisolites decrease in size, manganite becomes important and the silica and phosphorus contents increase. Still farther out, under conditions of oxygen deficiency, carbonates appear (rhodocrosite and manganocalcite) with glauconite, and there is marked enrichment in phosphates, sulphides and opal. Eventually the carbonates feather out and finally the ore-horizon is represented only by rare nodules of phosphorite.

(b) Deposits associated with calcareous sediments occur in the mountain ranges of west and central Siberia. They are mostly of late Pre-Cambrian age, but important occurrences are also found in the Cambrian of the Alatau. In the western Urals there are similar deposits of Permian age. The chief ore mineral in this type is manganocalcite.

(c) Deposits associated with clastic sedimente are represented at Labinskoye in the Tertiary of the North Caucasus. Chemical sediments are absent and the ores (psilomelane, pyrolusite or manganese carbonates) occur as cementing material.

In regionally metamorphosed deposits, formed originally by sedimentation, anhydrous minerals are characteristic, for example, braunite and hausmannite, associated with magnetite and hæmatite and quartz. The waters liberated during metamorphism have given rise to veinlets which are mineralogically closely related to the enclosing rocks. Specific cases of this kind in Lower Carboniferous chemical sediments (siliceous and ferruginous) of Kazakhstan are described by Betekhtin and Suslov in the publication cited (pp. 86-99 and 100-108 respectively). Under conditions of more intense metamorphism, manganese silicates develop (rhodonite, spessartite, tephroite, piedmontite, etc.), and carbonate ores poor in silica form manganous marble. Here again, especially along belts of tectonic disturbance, migration and redistribution of manganese is indicated by the occurrence of veins and lenses of concentrated ore. These veins, though otherwise resembling hydrothermal deposits, are free from elements such as gold, silver, lead and zinc; their origin is purely metamorphic. Vein and contact metasomatic deposits genetically connected with the hydrothermal activity of associated acid plutonic rocks are of far greater abundance and importance. The ores vary widely in composition and structure and often occur with a typical assemblage of sulphide minerals. In many of these deposits, however, there is evidence that the manganese compounds were not magmatic derivatives, but were taken from the manganiferous country rocks through which the hydrothermal solutions circulated.

All the above types of manganese deposits become secondarily enriched by weathering processes in the zone of oxidation, the end product being a pyrolusitepsilomelane complex. Betekhtin directs attention to the widespread development in the early stages of weathering of a manganic 'acid', $\mathrm{H}_{2} \mathrm{MnO}_{3}$, which occurs as dispersed colloidal particles (brown) or as colloform masses (black). Previously mistaken for manganite, this mineraloid is now distinguished as 'vernadite' after the geochemist Vernadsky, who originally predicted its discovery as a natural product. It is suggested that the various members of the psilomelane group may be salts of this acid. Concentration by chemical weathering is further intensified by the tendency of manganese hydroxides to migrate in colloidal solution and, activated by adsorbed alkali cations, to replace quartz and silicate minerals metasomatically.

ARThur Holmes.

\section{CHESHUNT EXPERIMENTAL STATION}

$T$ HE Experimental and Research Station at Cheshunt, Herts, has given a valuable lead to the changing demands of war-time cropping of the glasshouse industry. Discussion of problems relating to tomato and lettuce culture occupies all the annual report for 1943* and provides an index to the concentration of the industry upon food crops.

One of the most interesting items in the report by the director, Dr. W. F. Bewley, is of trials of two Russian varieties of outdoor tomatoes. Stambovoi Alpatyev has a neat dwarf habit, bears fruit of good shape, scarlet and sweet; it seems well worth further trial. Bizon proved to be coarser, and gave badly shaped fruit, though neither variety was resistant to frost exceeding two or three degrees. Two new varieties of lettuce, $5 a$ and $5 b$, are being tested commercially; they mature ten to fourteen days earlier than Cheshunt Early Giant. One important experi. ment with tomatoes involved the lowering of $p H$ of the soil by the addition of sulphur and sulphuric acid. Sulphur, at the rate of $4 \mathrm{oz}$. per square yard, gave only a slightly increased yield of fruit, but the soil, originally $p \mathrm{H} 8 \cdot 79$, was still $p H \quad 7.45$ at the end of the season. Sulphuric acid caused the soil $p \mathrm{H}$ to fall from $8 \cdot 62$ to $6 \cdot 39$ in a week ; but within a month it had risen again to $7 \cdot 84$. It would seem that some upward movement of soil bases takes place. It is fairly easy to make soil more alkaline, but it is not so easy to render it more acid, and the results of any further work on these lines will be awaited with interest.

An earlier annual report described resistance of the tomato varieties Riverside and Manx Marvel to attack by the fungus Verticillium albo-atrum. This does not now seem to hold under all cultural conditions, according to $\mathrm{P}$. $\mathrm{H}$. Williams. I. W. Selman has had a similar action of soil conditions in mind in his attempts to provide cultural factors which would enable tomato plants infected with spotted wilt virus to carry a reasonable crop. This should be a very practical approach to minimizing the damage caused by this disease, provided that it is linked with adequate hygiene at the end of the season. Dr. Selman's work on this question is not very conclusive as yet, but his correlations of mosaic infection and soil conditions with blotchy ripening have given much more definite results. Unequal ripening seems to depend largely upon the waterretaining properties of a particular soil mixture. Steaming and the addition of peat without appropriate manurial adjustments, or the use of composts with extreme fluctuations in water content, both favour the trouble, which is, moreover, always increased by mosaic infection. Mrs. Enid Sheard has investigated the pathology of tomato stem rot caused by the fungus Didymella lycopersici. The pathogen is more virulent if it has wintered out of doors than at temperatures of about $59^{\circ} \mathrm{F}$. Tomato seed does not seem to carry the fungus, and the only really susceptible alternative host so far discovered is the egg plant, Solanum melongena. Many organic sub. stances allow saprophytic growth of the fungus, which seems to grow best at a temperature of $20^{\circ} \mathrm{C}$. W. H. Read has tried many substances and treatments for control, without much success, though

- Twenty-ninth Annual Report of the Nursery and Market Garden Industries' Development Society, Ltd., Turner's Hill, Cheshunt, Herts,
1944. 